\section{BSE and risk to humans}

SIR - The developments in the handling of bovine spongiform encephalopathy (BSE) by the British authorities and those of the European Union do not provide much hope for clarifying the human risk issue in the near future. The finding of each new case of Creutzfeldt-Jakob disease and even of suspected cases in either the United Kingdom or any other country in Europe will add to the anxiety of the general public, whether it is rational or not.

Even the immediate withdrawal of all meat of potentially infected cows from the food chain will not convince consumers that beef is safe from that moment on, because past experience has shown that such measures cannot be properly enforced. The present dismal situation of both the beef industry and the consumers is due to previous failure by the UK government to commission adequate research programmes aimed at answering the crucial question of transmissibility of BSE to humans by all possible routes.

The recent report by Lasmézas et al. ${ }^{1}$ of BSE transmission to macaques has shown that at least 3 years ago scientists were aware of the necessity of such an approach. If at that time adequate experiments had been initiated, we would by now, and possibly even earlier, have had all the information needed. Instead of a study with 3 macaques and intracerebral injection of cow brain only, larger groups of chimpanzees should have been treated with intracerebral injections of BSE brain and beef, and administration of infected cow brain and meat and perhaps even milk by the cutaneous, intravenous and of course the oral route, the latter on a continuous feeding basis.

In the case of BSE, chimpanzees are the experimental animal of choice, not only because of the general argument that they are closer to man than macaques, but specifically because another transmissible prion disease in humans, kuru, is known to be transmitted to chimpanzees not only by infected human brain, but also by other tissues. Oral administration of kuruinfected human tissues, however, failed to induce the disease in chimpanzees ${ }^{2,3}$. Such a programme, though relatively expensive, would have cost a fraction of the present economic losses.

The argument we have heard, that chimpanzees were not available for this research in the United Kingdom, is obviously invalid, as the Dutch Biomedical Primate Research Centre has a large colony of chimpanzees available for research,

1. Lasmézas, C. I. et al. Nature 381, 743-744 (1996).

2. Gibbs, C. J. \& Gajdusek, D. C. Res. Publ. Assoc. Res. Nerv. Ment. Dis. 49, 383-410 (1971).

3. Gajdusek, D. C. \& Gibbs, C. J. Nature 240, 351 (1972). and research institutes in France can dispose of chimpanzees in the Gambia. These sources of chimpanzees and others became well known in the course of the European AIDS research programmes sponsored by the European Union.

D. W. van Bekkum

Comprehensive Cancer Centre Rotterdam,

PO Box 289,

3000 AG - Rotterdam,

The Netherlands

\section{P. J. Heidt}

Biomedical Primate Research Centre,

PO Box 3306 ,

$2280 \mathrm{GH}-$ Rijswijk,

The Netherlands

\section{Little to celebrate}

SIR - Celebrating its fiftieth anniversary on 1 August, the Institute of Advanced Studies (IAS) at the Australian National University in Canberra was delighted this year by a review that concluded, among other things, that no other institution in Australia, and few in the world, had achieved as much in research as IAS.

But Peter Pockley's article (Nature 382, 3 ; 1996) makes it clear that there has been little to celebrate. It concluded with a comment from Max Brennan, the chair of the Australian Research Council (ARC), that concern about his advice to government on this review amounted to nothing more than paranoia. Brennan now knows better, through the outrage expressed from all quarters of the globe at his wish to control Australia's leading independent research institution.

Having accepted a procedure jointly agreed with the Australian National University, Brennan invited 70 leading researchers to evaluate many hundreds of submissions and assessments. With three colleagues, Brennan then wrote more than 30 pages of 'advice' which, although by no means unanimously accepted by the council, was tabled in parliament as "the ARC Review of IAS". Making a mockery of the jointly agreed review, and overlooking the substantive evidence, Brennan advised government to give to ARC resources recommended for IAS, and, incredibly, to give ARC responsibility for IAS's future strategic planning and funding levels.

What does Brennan have in mind? Evidently embarrassed by high achievers, and unable to recognize his conflict of interest, he seems determined that, perhaps for the next 50 years, the IAS should be encumbered with the bureaucracy that constrains research in the rest of the country's universities. Australian researchers have to act now if they are to avoid being further fouled by the barnacles of bureaucracy that will drag them away from the leading edge.

Perhaps the treatment of the IAS review was the exposé that ARC had to have. Under a new government there may be an opportunity to restructure ARC into a credible body in support of research, one that respects peer opinion. It must be kept out of policy, away from the pretexts of strategic planning and from destructive meddling beyond this brief. If integrity and confidence can be restored in the ARC, then the anguish underlying the fiftieth anniversary of IAS can be transformed into a gift to Australia's researchers for the future.

\section{Barry Osmond}

(Director)

Research School of Biological Sciences, Institute of Advanced Studies, Australian National University,

Box 475,

Canberra, ACT 2601, Australia

Present address: Duke University Marine Laboratory, Beaufort, North Carolina 28516, USA.

\section{Tip of the iceberg}

SIR - Daedalus's idea of halting sea-level rise if there is global warming by slowing the melting rate of land ice is only a small part of the answer ${ }^{1}$. In future projections of sea-level rise ${ }^{2,3}$, the major contributor is thermal expansion of the oceans. The melting of alpine glaciers and small ice caps (GSICs) accounts for only about 35 per cent of the total sea-level rise to 2100 under the central projection (some $17 \mathrm{~cm}$ out of a total of $49 \mathrm{~cm}$ compared with $25 \mathrm{~cm}$ for expansion).

Beyond 2100, the relative contribution from GSICs is smaller because their total ice mass is equivalent only to about $30 \mathrm{~cm}$ of sea-level rise. Slowing the rate of heat sequestration by the oceans is not the answer, as this will only accelerate the warming of the atmosphere (and add to the ice-melt contribution!). Daedalus may be interested in reading about some of the imaginative geo-engineering 'fixes' that have been suggested by others (such as those listed by the US National Academy of Sciences ${ }^{4}$ ) before speculating further.

Tom M. L. Wigley

National Center for

Atmospheric Research,

PO Box 3000 ,

Boulder,

Colorado 80307-3000, USA

e-mail:wigley@ncar.ucar.edu

1. Jones, D. Nature 381, 196 (1996).

2. Raper, S. C. B., Wigley, T. M. L. \& Warrick, R. A. in Sea-Level Rise and Coastal Subsidence: Causes, Consequences and Strategies (eds Milliman, J. D. \& Haq, B. U.) 11-45 (Kluwer, Dordrecht, 1996).

3. Warrick, R. A. et al. in Climate Change 1995: The Science of Climate Change (eds Houghton, J. T. et al.) 558 405 (Cambidge Univ. Press, New York, 1996). 358-405 (Cambinge Univ. Press, New York, 1996).

4. National Academy of Sciences Policy Implications of Greenhouse Warming (National Academy Press, Washington, DC, 1991).

NATURE · VOL 382 · 15 AUGUST 1996 